\title{
Connecting the Chains: Emotional Quotation, Ethics, and Legal Profession Ethics
}

\author{
Aditia Arief Firmanto ${ }^{1}$, Rissa Afni Martinouva² \\ 1 Faculty of Law, Univeritas Malahayati, Indonesia \\ aditia_ariffirmanto@yahoo.co.id \\ 2 Faculty of Law, Universitas Malahayati, Indonesia \\ rissa.afni.m@gmail.com
}

\begin{abstract}
Introduction to The Problem: Emotional intelligence is in the form of feelings and emotions, and contains the direction and intensity of one's judgment or expression of feelings expressed on the object of attitude. Emotional intelligence or Emotional Quotient (EQ) is essential. Intellectual Intelligence (IQ) cannot run properly without the participation of an emotional appreciation of the ethics of law school students. Ethics also has a massive role in determining the good and bad of human behavior, behavior, or actions. While a legal profession is a job carried out by a group of people who have the legal expertise to support their lives. Students who graduate can choose their major according to the skills taught in Higher Education. From the previous three concepts arise one main problem on how the connection between EQ-IQ, ethics, and legal profession ethics.

Purpose/Objective Study: The objective of this study is to find out the correlation of emotional intelligence toward the ethics of law faculty students at Universitas Malahayati and the correlation of students' ethics toward the legal profession.

Design/Methodology/Approach: In gathering data, the researchers used quantitative (questionnaire) and qualitative methods supported by interviews. To analyze the data, the researcher used quantitative descriptive with the Linkert Scale approach, and the results of the scale are accumulated with the regress linear technique.

Findings: The results of this study show that there was a significant correlation of emotional intelligence to the ethics of law school students at Universitas Malahayati. Based on the results of the hypothesis test, the value of $r$ is 0.854 with $P=0.000$ where $(p<0.01)$. It indicates that there is a correlation between emotional intelligence and the ethics of law faculty students at Universitas Malahayati. This finding suggests that the higher the emotional intelligence, the higher the ethics, conversely the lower the emotional intelligence possessed by individuals, the lower the ethics of law school students. Additionally, the correlation of emotional intelligence toward ethics by 0.854 means that emotional intelligence has a contribution of $85.4 \%$ as a variable that affects the ethics of law school students. The remaining $14.6 \%$ of emotional intelligence is influenced by other factors. The correlation between ethics and the legal profession is that by implement ethics in the legal profession, the legal service
\end{abstract}


will gain the society's trust. People tend to lean to excellent and professional legal practitioners who have embodied the ethics in their service and their personalities.

Paper Type: Research Article

Keywords: Emotional Quotations; Ethics; Legal Profession Ethics

\section{Introduction}

Ethics is a standard of morality that evaluates an action (Hudiarini, 2017). It is a standard of behavior set by a community in an area even where education can become an ethical standard (Sutrisno, 2016). Universitas Malahayati is a private university located in Bandar Lampung. Its vision is 'becoming a leading international standard university in the development of science and technology-based on religious ethics.' Ethics to the students is considered to be closely related to the ability to control the misdeed activities.

Furthermore, ethics also has become the foundation to carry out activities that still refer to or see values and norms (Suseno, 1987). However, based on the results of interviews of five of the six Law Faculty lecturers, there are still some students who do not have good ethics. Such examples are like cheating during exams, sleeping during the class, chatting or making noise while in college, smoking at the campus, not being friendly to the academic community, not doing their work on time. Students, as part of the educational component, have a duty to carry out the learning process as well as possible.

The learning process is complex and comprehensive (Aditya, 2016). Many people argue that to achieve high achievements in learning, they must have a high Intelligence Quotient (IQ) because intelligence is a potential provision that will facilitate learning and, in turn, will produce optimal learning achievement (Purnama, 2016). The essence of intelligence is the ability to set and maintain a goal, to make adjustments to achieve that goal, and to assess the state of self critically and objectively (Herlinda, Wasidi, \& Sulian, 2018). Meanwhile, Daniel Goleman stated that emotional intelligence is the ability of a person to manage his emotional life with knowledge, maintain emotional harmony and disclosure through self-awareness skills, self-control, self-motivation, empathy, and social skills (Goleman, 2011; Prawitasari, 1998). Intellectual intelligence (IQ) only contributes $20 \%$ to be a success, while $80 \%$ is added by other strength factors, including emotional intelligence or Emotional Quotient (EQ) (Badjuri, Indriasih, \& Sumiyati, 2019).

A legal profession is a job carried out by a group of people who have the legal expertise to support their lives. Students who graduate later can choose their major according to the skills taught in Higher Education (Burhanudin, 2018). The skills needed for the legal profession are taught in tertiary institutions. A successful job on the Legal Profession depends on the quality and achievements of the law teaching process (Hendrawati, Adhisyah, Yudhanto, \& Putra, 2016). The fields of the legal profession are judges, attorneys, lawyers, notaries, and lecturer at the Faculty of Law. However, 


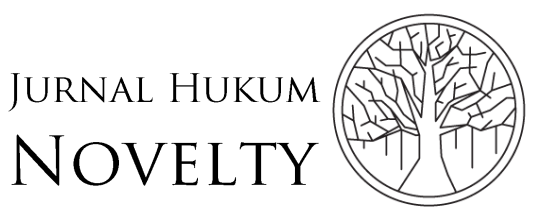

Volume 11, Issue 01, 2020, pp. 86-94

P-ISSN: $1412-6834$

E-ISSN: 2550-0090

in the broadest definitions, the functions of the legal profession are not limited to traditional features as legal technicians. Its duties include legal counseling, legal negotiating, documents, and legislature drafting, even law-making in broad terms (Ibrahim, 2015).

The objective of this study is to find out the correlation of emotional intelligence toward the ethics of law faculty students at Universitas Malahayati and the correlation of students' ethics toward the legal profession. Bad ethics of the students on campus will give a negative impression for the university in general and particularly for the Faculty. Therefore, the students are expected to be ethical in the environment of the campus. Based on the above phenomenon, the researchers want to find out the correlation of emotional intelligence toward the ethics of law faculty students at Universitas Malahayati as well as the ethical relationship of students with the legal profession.

\section{Methodology}

This study used mixed methods, both quantitative and qualitative. In the quantitative process, this study uses two variables: the dependent variable and the independent variable. The dependent variable is used to measure ethics, and the independent variable is used to measure emotional intelligence. Emotional intelligence here is intended as feelings and emotions and contains the direction and intensity of one's judgment or expression of opinions expressed towards the object of attitude (Gitosaroso, 2012). Meanwhile, ethics means as knowledge on how to vision of human action (Sutrisno, 2016). In the qualitative process, it is intended as a process of description or structured explanation between EQ, ethics, and ethics of the legal profession with the basis of quantitative data that has been obtained.

The design of this research is observational analytic with a quantitative approach to measure the influence of emotional intelligence on the ethics of law faculty students at Universitas Malahayati (Azwar, 2003). The measurement uses a total sampling technique which means the number of samples is equal to the total population of all students of the Faculty of Law, Universitas Malahayati are 92 students. The overall sampling is based on the characteristics of the student in the academic year of 2016 and 2017. The total sampling is used because the total population is less than 100 from the entire community needs to be used as a whole research sample (Sugiyono, 2007).

The variable of Emotional Intelligence is measured by consisting of six indicators that have 30 statements with a Linkert scale of 1 to 5 . The instrument uses six aspects of skills that can be used as emotional intelligence measurements, namely elements of skills related to moral behavior, skills related to thinking, skills related to problemsolving, skills related to social interaction, skills related to academic and work success, skills related to emotional strength. The scale that reveals the points in the 
scale of the Linkert model prepared by taking into account the nature of the favorable and unfavorable (Azwar, 2003).

The ethic variable is measured by giving a questionnaire consisting of 25 statements regarding student approval and disapproval of ethics with a scale of 1 to 5 . The level that will reveal the items in the Linkert model scale compiled by taking into account the nature of the favorable and unfavorable. The two variables above are tested for validity and reliability using content validity and Alpha Combrach formula. A validity test is done by estimating the examination of the contents of the test with rational analysis or through professional judgment. Meanwhile, the reliability is done through an internal consistency approach to avoid the problems commonly caused by the retesting approach and parallel form approaches (Azwar, 2003).

The preparation of the measuring instrument of this study uses two scales as data measurement tools, namely the Emotional Intelligence Scale and the ethical scale. The scale is closed in the sense that the subject of the researcher is only asked to choose one of the five alternative answers that have been provided, and that best suits the subject's self-state. This scale uses multiple-choice item types in the form of multiple choices with five alternative answers, namely SS (Strongly Agree), S (Agree), N (Neutral), TS (Disagree), STS (Strongly Disagree) in the form of favorable and unfavorable statements (Azwar, 2003). Ratings are given for favorable reports, namely SS (Strongly Agree) gets a score of 5, S (Agree) receives a score of 4, N (Neutral) gets a score of 3, TS (Disagree) gets a score of 2, and STS (Strongly disagree) receives a score 1 . For the Unfavorable statement, SS (Strongly Agree) gets a score of $1, \mathrm{~S}$ (Agree) gets a score of 2, N (Neutral) gets a score of 3, TS (Disagree) gets a score of 4 , and STS (Extremely not Agree) gets a score of 5.

\section{Results and Discussion}

\section{Corresponding the Data Between EQ and Ethics}

In the Emotional Quotation measurement, based on the Pearson Product Moment correlation, in case the items that have a discriminatory power index are equal to or greater than 0.30 , the number exceeds the number of subjects planned to be scaled. The researcher can choose items that have the highest discrimination power index (Azwar, 2003). Based on the results of the validity test of emotional intelligence measuring instruments, out of a total of 30 items, 19 valid items have a correlated score of total correlation items ranging from 0.300 to 0.634 . While the reliability obtained, based on the Alpha Cronbach formula, is 0.787 (Table 1), which means that the results are considered reliable. It is based on that the scale reliability coefficient, which is less than 0.6 , is considered not good. The reliability coefficient of 0.7 is acceptable, while above 0.8 is good (Azwar, 2003).

The results of ethical measurements using the same technique have a score of corrected items total correlations that move from 0.301 to 0.630 . Of the 25 questionnaires tested on ethics, only five were declared null and void. While ethical 


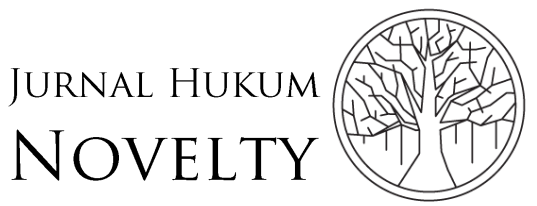

Volume 11, Issue 01, 2020, pp. 86-94
P-ISSN: $1412-6834$

E-ISSN: 2550-0090

reliability obtained a result of 0.848 , according to the basis presented by Azwar in the paragraph above (Azwar, 2003), the value indicates excellent reliability.

Table 1. The reliability of Emotional Quotation and Ethic

\begin{tabular}{lcc}
\cline { 2 - 3 } & Cronbach's Alpha & N of Items \\
\hline Emotional Quotation & 0.787 & 30 \\
\hline Ethics & 0.848 & 30 \\
\hline
\end{tabular}

Through the hypothesis using the Product Moment Analysis technique from Pearson using Statistical Product and Service Solution (SPSS) version 20.0, the value of 0.854 was obtained with $\mathrm{P}=0.000$ where $\mathrm{p}<0.01$. Based on the analysis, the result shows that the emotional intelligence variable contributed effectively by $85 \%$. The percentage is obtained from the value of $r$ multiplied by 100 :

$$
0.854 \times 100=85.4 \%
$$

It shows that there is a correlation between emotional intelligence and the ethics of law school students at Univeritas Malahayati. It means that the higher the emotional intelligence, the higher the ethics. Conversely, the lower the emotional intelligence possessed by individuals, the lower the ethics of law faculty students. The correlation between emotional intelligence and ethics by 0.854 means emotional intelligence has a contribution of $85.4 \%$ as a variable that affects the ethics of law school students. The remaining $14.6 \%$ of emotional intelligence is influenced by other factors.

Based on the findings, treatment improvement for law faculty students may be conducted, for example, by providing training to improve emotional intelligence. All the more, this correlation will influence later with further action after the students graduate from the law faculty. As a result, the legal profession that will be carried out by law graduates can refer to the basic ethics that has been taught since the university.

\section{The Correlation between Law Student Ethics and Legal Profession Ethics}

There is a close relationship between values, norms, sanctions, and regulations (Sutarni, 2018). Behan also says that a value is a measure realized or unrealized by a society or group to determine what is right, what is good, and so on. Norms are assumptions about one's values and moral attitude of a person or a society, while ethics is a normative philosophy or critical thinking about morality (Hudiarini, 2017).

Understanding ethics is based on the evaluation of different interpretations. The interpretation itself is contained in the norms and regulations in which should be applied and obeyed by society. It is because humans use the norms or regulations as a code of conduct.

Students' ethics in law faculty of Universitas Malahayati is governed by a Student Code of Ethics guidebook published by Universitas Malahayati. The code of ethics is 
compiled to maintain propriety and order in the Academic environment of Universitas Malahayati (Farich, Kadafi, \& Tarmizi, 2014).

Students' ethics in the rules of the Code of Ethics are summarized in several aspects, namely in terms of appearance, aspects of behavior towards personal and others, time management aspects, and environmental aspects. Ethics, in terms of appearance, is to dress politely. The ethics of expression is such as to respect one another and not to do evil. Ethics in terms of time is like respecting and keeping time in the learning process of students on campus. Lastly, from the environmental side is to maintain cleanliness and maintain the beauty of the surroundings (Farich, Kadafi, \& Tarmizi, 2014).

Violations are divided into three, namely violations of the law, violations of moral ethics and professional ethics, and violations of academic ethics. Violation of the law is when a student violates the code in the form of a crime or misuse of drugs, or narcotics will be subject to suspension from the university, the criminal matter will be submitted to the authorities. Violations of moral ethics and professional ethics are students who violate moral ethics, the profession (conducting consultations without supervision, leaking questions, etc.), will be subjected to sanctions until the termination of the study. Academic ethics violations are students who violate academic ethics, such as cheating, plagiarizing, damaging recordings on a computer, leaking questions, or the like will be subject to sanctions until termination of the study (Farich, Kadafi, \& Tarmizi, 2014).

Students who have good ethics will become well-behaved alumni. Law Faculty students who have good emotional intelligence and good ethics when they graduate will become competent and professionals. The profession, in general, has at least two principles that must be upheld, namely (Sutrisno, 2016):

1. Principles for carrying out the profession responsibly

2. Respect the rights of others

Professional standards must be differentiated from behavioral standards. Occupational standards cannot be separated from the value system that applies to the professional organization. The values contained in the professional code of ethics are the benchmark used as the basis for carrying out the profession for its members (Muhaimin, 2017; Sutrisno, 2016). Student ethics is essentially a view of life and guidance on how students should behave. This code of conduct can be a guide to good and bad deeds. So that the ethical codes and empathetic ways of thinking of students will become the correlations and decisive actions when students get a bachelor's degree and work as law enforcers. Therefore, student ethics here is a scientific reflection of human behavior in terms of good and bad norms (Tanyid, 2014).

Legal students should be aware of their ethic's behavior. It is because, after their graduation, they need to be professional legal experts who are giving their time and abilities to help people in need. The ethic's awareness student must hold on to it are as below mentioned (Shidarta, 2006): 


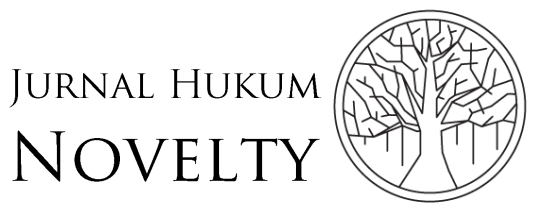

Volume 11, Issue 01, 2020, pp. 86-94
P-ISSN: $1412-6834$

E-ISSN: 2550-0090

1. The ability for ethical awareness (ethical sensibility)

2. The ability to think ethically (moral reasoning)

3. The ability to act morally (ethical conduct)

4. The capacity for ethical leadership (ethical leadership)

Those capabilities are the necessary foundation of the character, personality, and behavior of legal professionals. Ethical awareness can be measured from the ability of legal professionals to determine aspects of situations and conditions that have moral interests. The ability to think ethically concerns matters that are closely related to the tools and frameworks that are considered to constitute the entire ethical education of the legal profession. The ability to act ethically is a manifestation of sincerity; this will be demonstrated by the behavior that is acted on in ethical and correct decision making. Moral failure occurs because of an error. It might be caused by the person concerned afraid of not going up in rank, fear of not getting a client, and so forth. The ability to lead ethically is the ability to act ethically leadership which certainly has a relationship with the level of sincerity.

The phenomenon above has caused the Consortium of Legal Studies to consider the need to incorporate the Legal Professional Ethics into the Law Philosophy course as a round of study. It has also been confirmed by a Decision of Education and Culture Ministry of the Republic of Indonesia No: 7/0/1993 on the National Curriculum that applies in the National Higher Education Bachelor of Law Program at the Faculty of Law (Burhanudin, 2018).

The form of legal service, in general, is to practice legal capacity as a social service that requires legal assistance. Therefore, in carrying out the profession, there are the basic rules of professional ethics, namely (Krisharyanto, 2006):

1. The profession must be considered as a service, so selflessness becomes a characteristic in carrying out the occupation. The purpose of 'no strings attached' here is that the decisive consideration in making decisions in the interests of the client and the public interest, not his interests. If the selfless nature is ignored, then professional development will lead to the use that leads to the misuse of fellow human beings who are experiencing difficulties or distress

2. Professional service in providing the priority of clients' interest refers to the interests or noble values as norms of criticism that motivate attitudes and actions

3. Professional development must always be oriented towards society as a whole

4. Professional development should be enthusiastic about solidarity among fellow professionals so that competition is in a healthy environment, as well as to ensure quality and improve the quality of the profession bearer.

From the description above, it can be seen how close the ethics relationship of students with the legal profession. With this ethics, the legal professionals can carry out the duties (devotion) of their occupation well, to create respect for human dignity that will ultimately give birth to justice amid society. 


\section{Conclusion}

The positive correlation between emotional intelligence and the ethics of law students from the data obtained is a concrete step for legal education in preparing the right legal professions. However, this mutual correlation deserves to be connected continuously in the personal awareness of a scholar when he plays the role of law enforcement in various fields of his profession. The numerical value of this data certainly needs to be supplemented by a more comprehensive study involving all higher education institutions that provide legal learning facilities. Thus, it can be traced back to the quality of law graduates in Indonesia holistically measured and parsed since the time of education, graduation, to the active involvement in the legal profession.

\section{References}

Aditya, D. Y. (2016). Pengaruh penerapan metode pembelajaran resitasi terhadap hasil belajar Matematika siswa. SAP (Susunan Artikel Pendidikan), 1(2). https://doi.org/10.30998/sap.v1i2.1023

Azwar, S. (2003). Metode Penelitian. Yogyakarta: Pustaka Pelajar.

Badjuri, Indriasih, A., \& Sumiyati, S. (2019). Pengaruh kecerdasan intelektual, kecerdasan emosional dan kecerdasan spiritual terhadap pemahaman PKP Mahasiswa PGPAUD UPBJJ UT Semarang. Inopendas Jurnal Ilmiah Kependidikan, 2(1). Retrieved from https://jurnal.umk.ac.id/index.php/pendas/article/view/3442

Burhanudin, A. A. (2018). Peran etika profesi hukum sebagai upaya penegakan hukum yang baik. Jurnal El-Faqih, 4(2). Retrieved from https://ejournal.iaifakediri.ac.id/index.php/elfaqih/article/view/43

Farich, A., Kadafi, K., Tarmizi, T. (2014). Kode etik Unmal. Lampung: LPPM Unmal.

Gitosaroso, M. (2012). Kecerdasan emosi (emotional intelligence) dalam tasawuf. Jurnal Kathulistiwa-Journal of Islamic Studies, 2(2). Retrieved from http://moraref.kemenag.go.id/documents/article/97406410605886749/dow nload

Goleman, D. (2011). Working with emotional intellegence. New York: Bantam.

Hendrawati, H., Adhisyah, S. V. D. M., Yudhanto, M. C., \& Putra, N. S. (2016). Aspek penegakan kode etik hakim dalam mewujudkan kekuasaan kehakiman yang bermartabat dan berintegritas. Varia Justicia, 12(1). Retrieved from http://journal.ummgl.ac.id/index.php/variajusticia/article/view/346

Herlinda, D., Wasidi, \& Sulian, I. (2018). Hubungan kecerdasan emosi dengan kemampuan bersosialisasi siswa di lingkungan Sekolah Kelas VII SMP Negeri 03 Mukomuko. Consilia, 1(3). Retrieved from https://ejournal.unib.ac.id/index.php/j_consilia/article/viewFile/6553/3194

Hudiarini, S. (2017). Penyertaan etika bagi masyarakat akademik di kalangan dunia pendidikan tinggi. Jurnal Moral Kemasyarakatan, 2(1). https://doi.org/https://doi.org/10.21067/jmk.v2i1.1699

Ibrahim, U. (2015). Analisis yuridis pemahaman utilitarisme etika dan profesi hukum. Jurnal Cahaya Keadilan, 3(2). Retrieved from http://ejournal.upbatam.ac.id/index.php/cahayakeadilan/article/view/967

Krisharyanto, E. (2006). Fungsi etika profesi hukum bagi advokat dalam menegakan hukum. Perspektif, 11(2). Retrieved from http://jurnalperspektif.org/index.php/perspektif/article/view/400 
Muhaimin, M. (2017). Penerapan Asas Oportunitas oleh Kejaksaan Agung bertentangan dengan Asas Legalitas dan "Rule of Law." Jurnal Penelitian Hukum De Jure, 17(1), 108. https://doi.org/10.30641/dejure.2017.V17.108-122

Prawitasari, J. E. (1998). Kecerdasan emosi. Buletin Psikologi, 6(1). Retrieved from https://journal.ugm.ac.id/buletinpsikologi/article/view/13280

Purnama, I. M. (2016). Pengaruh kecerdasan emosional dan minat belajar terhadap prestasi belajar Matematika di SMAN Jakarta Selatan. Formatif: Jurnal Ilmiah Pendidikan MIPA, 6(3). https://doi.org/10.30998/formatif.v6i3.995

Shidarta, A. (2006). Moralitas profesi hukum: Suatu tawaran kerangka berfikir. Bandung: Refika Aditama.

Sugiyono. (2007). Metode penelitian kuantitatif kualitatif dan R\&D. Bandung: Alfabeta.

Suseno, F. M. (1987). Etika dasar masalah-masalah pokok filsafat moral. Yogyakarta: Kanisius.

Sutarni. (2018). Manusia, moralitas dan hukum. Jurnal Hukum Kaidah: Media Komunikasi Dan Informasi Hukum Dan Masyarakat, 18(1). Retrieved from https://jurnal.uisu.ac.id/index.php/jhk/article/view/916

Sutrisno. (2016). Etika profesi hukum. Jakarta: Andi.

Tanyid, M. (2014). Etika dalam Pendidikan: Kajian etis tentang krisis moral berdampak pada pendidikan. Jurnal Jaffray, 12(2), 235. https://doi.org/10.25278/jj71.v12i2.13 